\title{
Patterns of partial edentulism based on Kennedy's classification among patients reporting to Nepal Medical College and Teaching Hospital
}

\author{
Rana SB', Acharya B², Bhochhibhoya A', Sharma R', Acharya J33, Mainali A4 \\ 'Samskar Bickram Rana, Lecturer, ${ }^{2}$ Binod Acharya, Professor, 'Amar Bhochhibhoya, Lecturer, 'Rinu Sharma, Lecturer, \\ Department of Prosthodontics, ${ }^{3}$ Jemish Acharya, Lecturer, Department ofCommunity and Public Health Dentistry, ${ }_{1}^{4}$ Apekshya \\ Mainali, Associate Professor, Department of Oral Medicine and Radiology, Nepal Medical College and Hospital, Atterkhel, \\ Kathmandu, Nepal.
}

\begin{abstract}
Background: Edentulism is a sequel of tooth loss which leads to impairment of normal function, comfort, aesthetics and speech. It also leads to various undesirable consequences like occlusal discrepancies, migration and spacing of surrounding teeth, supra eruption, loss of space, temporomandibular disorders and other unwanted changes. Little is known about the prevalence of patterns of edentulism in Nepal.

Objectives: To assess the prevalence of Kennedy's classification on partially edentulous patients.

Methodology: A prospective cross-sectional study was carried out among 300 patients within the age of 18-80 years visiting the Department of Oral Medicine and Radiology, College of Dental Science and Hospital -Nepal Medical College with at least one missing tooth from Jan 2018-March 2018.

Results: Out of 300 patients enrolled, a majority were female (178; 59.3\%). The patients mostly affected by partially edentulous condition were among the age group of 51 to 60 years $(78 ; 26 \%)$. The distribution of partially edentulous areas were similar in maxillary $(80 ; 26 \%)$ and mandibular $(85 ; 28.3 \%)$ arches and $45 \%$ of the patients $(n=135)$ had one or more missing tooth/teeth on both arches. Kennedy's class III was found in more than $31 \%$ of the patients $(n=94)$ in the maxillary arch and $30 \%(n=91)$ in the mandibular arch. Likewise, Kennedy's class III with modification 1 was seen in $21 \%$ $(n=62)$ cases in the maxillary and $24 \%(n=72)$ cases in the mandibular arch.

Conclusion: Kennedy's class III and Kennedy's class III with modification1 were the most common type of pattern of partially edentulous area on both arches.
\end{abstract}

Key words: Applegate rule; Kennedy's class; Partial edentulism

DOI: https://doi.org/10.3126/jkmc.v7i4.23313

\section{INTRODUCTION}

$\mathrm{E}$ dentulism is the state of being edentulous without natural tooth/teeth. Edentulism not only leads to impairment of normal function, comfort, aesthetics and speech, but also leads to various undesirable sequela like occlusal discrepancies, migration and spacing of surrounding teeth, supra eruption, loss of space, temporomandibular joint disorders, and other unfavorable conditions ${ }^{(1-3)}$.

Address for correspondence

Dr. Samskar B Rana

Lecturer, Department of Prosthodontics

Nepal Medical College, Kathmandu, Nepal.

E-mail:samskar.rana@gmail.com
Documenting the pattern of partial tooth loss is very important for identifying the prosthetic needs of the studied community as well as aiding the provision of educational and preventive materials suitable for this population ${ }^{2}$. Several methods of classification of partially edentulous arches have been proposed and are in use e.g. by Beckett, Godfrey, Swenson, Friedman, Wilson, Skinner, Applegate, Avant, Miller and others ${ }^{3}$. At present, Kennedy's classification is the most widely used and accepted because of its simplicity, ease of application, immediate visualization of the type of partially edentulous arch being considered and differentiation between tooth borne and tooth tissue borne partial dentures ${ }^{4}$. Monitoring the occurrence of partial edentulism is important because it is an indicator of both population health and adequacy of a country's oral 
health care system ${ }^{5}$.The absence of organized diagnostic criteria for partial edentulism has been a longstanding impediment ${ }^{6}$.

The patterns of tooth loss have been evaluated in many selected populations in different countries and the frequency of partial edentulousness seems to vary widely between different countries. The prevalence and patterns of tooth loss have been studied to a certain extent in other countries but little is known in $\mathrm{Nepal}^{7}$. We conducted this cross-sectional study among Nepalese patients visiting Nepal Medical College to estimate the prevalence of the pattern of edentulism.

\section{METHODOLOGY}

The study was conducted at the Department of Oral Medicine and Radiology, Nepal Medical College and Hospital (College of Dental Sciences and Hospital). A single researcher collected patients' socio-demographic data and conducted clinical examination with the help of diagnostic instruments (mouth mirror and probe) to record Kennedy's classification system and Applegate modifications. Age and gender were obtained from patients' hospital record card. Data was collected in a three month period from $1^{\text {st }}$ January to $30^{\text {th }}$ March; 2018. The minimum sample size of this study was estimated to be two hundred, based on the prevalence of awareness regarding partial edentulism from a prior study. We enrolled 300 patients in this study within the age group of 18-80 years with at least one missing tooth. Patients who were completely edentulous and those unwilling to participate were excluded.

Ethical Consideration: Ethical approval was taken from the Research and Ethical Sub-Committee; Nepal Medical College (NMC-RESC) dated 15 $15^{\text {th }}$ December 2017 with reference number: 32-074/075.

\section{RESULTS}

Out of 300 patients, $40.7 \%$ were male and $59.3 \%$ were female (Table 1). When categorized by age groups, most patients with partial edentulism belonged in the range of51 to 60 years $(78 ; 26.0 \%)$ (Table 2 ).

Nearly half of the patients had partial edentulism on both arches $(135 ; 45.0 \%)$, while $26.7 \%$ had partial edentulism on the maxillary arch only $(n=80)$ and $28.3 \%$ on the mandibular arch only $(n=85)$ (Table 3$)$. In the maxillary arch, Kennedy's class III was the most common pattern of partial edentulism $(94 ; 31.3 \%)$, followed by Kennedy's class III with modification 1 (62; 20.7\%) (Table 4). Similarly in the mandibular arch, Kennedy's class III was the most prevalent $(91 ; 30.3 \%)$ followed by Kennedy's class III with modification 1 (72; $24.0 \%)$ patients (Table
5). Among all age groups in both arches, Kennedy's class III and Kennedy's class III with modification 1 were the two most common pattern of partial edentulism (Tables 6 and 7).

Table 1: Gender Distribution of partially edentulous patients

\begin{tabular}{lcc}
\hline Gender & Frequency & Percent \\
\hline Male & 122 & 40.7 \\
\hline Female & 178 & 59.3 \\
\hline Total & $\mathbf{3 0 0}$ & $\mathbf{1 0 0}$ \\
\hline
\end{tabular}

Table 2: Age Distribution of partially edentulous patients

\begin{tabular}{lcc|}
\hline Age & Frequency & Percent \\
\hline 18-30 years & 50 & 16.7 \\
\hline $31-40$ years & 49 & 16.3 \\
\hline $41-50$ years & 61 & 20.3 \\
\hline 51-60 years & 78 & 26.0 \\
\hline $61-70$ years & 47 & 15.7 \\
\hline 71-80 years & 15 & 5.0 \\
\hline Total & $\mathbf{3 0 0}$ & $\mathbf{1 0 0 . 0}$ \\
\hline
\end{tabular}

Table 3: Arch wise distribution of partial edentulism

\begin{tabular}{lcc}
\hline Arch & Frequency & Percent \\
\hline Maxillary only & 80 & 26.7 \\
\hline Mandibular only & 85 & 28.3 \\
Both arches & 135 & 45.0 \\
Total & $\mathbf{3 0 0}$ & $\mathbf{1 0 0 . 0}$ \\
\hline
\end{tabular}

Table 4: Distribution of partial edentulism according to Kennedy's classification and Applegate's rule in maxillary arch

\begin{tabular}{|ccc|}
\hline Kennedy's class with modification & Frequency & Percent \\
\hline I II & 10 & 3.3 \\
\hline III & 8 & 2.7 \\
\hline IV & 94 & 31.3 \\
\hline I 1 & 11 & 3.7 \\
\hline I 3 & 4 & 1.3 \\
II 1 & 3 & 1.0 \\
\hline II 2 & 1 & .3 \\
\hline III 1 & 4 & 1.3 \\
\hline III 2 & 62 & 20.7 \\
\hline III 3 & 12 & 4.0 \\
\hline III 4 & 3 & 1.0 \\
\hline None & 3 & 1.0 \\
\hline Total & 85 & 28.3 \\
\hline
\end{tabular}


Table 5: Distribution of partial edentulism according to Kennedy's classification an Applegate's rule in mandibular arch

\begin{tabular}{|ccc|}
\hline Kennedy's class with modification & Frequency & Percent \\
\hline I & 10 & 3.3 \\
\hline II & 1 & .3 \\
\hline III & 91 & 30.3 \\
\hline IV & 22 & 7.3 \\
\hline I & 2 & .7 \\
\hline II 1 & 1 & .3 \\
\hline II 2 & 5 & 1.7 \\
\hline III 1 & 2 & .7 \\
\hline III 2 & 72 & 24.0 \\
\hline III 3 & 12 & 4.0 \\
\hline none & 2 & .7 \\
\hline Total & 80 & 26.7 \\
\hline & $\mathbf{3 0 0}$ & $\mathbf{1 0 0 . 0}$ \\
\hline
\end{tabular}

Table 6: Pattern of partial edentulism in relation to age in maxillary arch

\begin{tabular}{|c|c|c|c|c|c|c|c|c|c|c|c|c|c|c|}
\hline \multirow{2}{*}{ Age group } & \multicolumn{13}{|c|}{ Maxillary } & \multirow{2}{*}{ Tota } \\
\hline & I & II & III & IV & 11 & 13 & II 1 & II 2 & III 1 & III 2 & III 3 & III 4 & None & \\
\hline $18-30$ years & 0 & 0 & 19 & 0 & 0 & 0 & 0 & 0 & 8 & 0 & 0 & 0 & 23 & 50 \\
\hline $31-40$ years & 0 & 2 & 13 & 0 & 0 & 1 & 0 & 0 & 5 & 1 & 0 & 1 & 26 & 49 \\
\hline $41-50$ years & 1 & 1 & 31 & 2 & 0 & 1 & 0 & 0 & 11 & 2 & 0 & 0 & 12 & 61 \\
\hline $51-60$ years & 5 & 2 & 14 & 6 & 2 & 0 & 1 & 2 & 24 & 2 & 0 & 2 & 18 & 78 \\
\hline $61-70$ years & 4 & 2 & 11 & 2 & 2 & 1 & 0 & 2 & 9 & 6 & 2 & 0 & 6 & 47 \\
\hline $71-80$ years & 0 & 1 & 6 & 1 & 0 & 0 & 0 & 0 & 5 & 1 & 1 & 0 & 0 & 15 \\
\hline Total & 10 & 8 & 94 & 11 & 4 & 3 & 1 & 4 & 62 & 12 & 3 & 3 & 85 & 300 \\
\hline
\end{tabular}

Table 7: Pattern of partial edentulism in relation to age in mandibular arch

\begin{tabular}{|c|c|c|c|c|c|c|c|c|c|c|c|c|c|}
\hline \multirow{2}{*}{ Age group } & \multicolumn{12}{|c|}{ Mandibular } & \multirow[t]{2}{*}{ Total } \\
\hline & I & II & III & IV & 11 & 13 & II 1 & II 2 & III 1 & III 2 & III 3 & none & \\
\hline $18-30$ years & 0 & 0 & 14 & 4 & 0 & 1 & 0 & 0 & 8 & 3 & 0 & 20 & 50 \\
\hline $31-40$ years & 0 & 0 & 23 & 1 & 0 & 0 & 0 & 1 & 17 & 0 & 0 & 7 & 49 \\
\hline $41-50$ years & 0 & 0 & 17 & 3 & 1 & 0 & 1 & 0 & 15 & 2 & 1 & 21 & 61 \\
\hline $51-60$ years & 5 & 1 & 23 & 10 & 0 & 0 & 4 & 0 & 16 & 3 & 0 & 16 & 78 \\
\hline $61-70$ years & 5 & 0 & 9 & 2 & 1 & 0 & 0 & 1 & 16 & 1 & 1 & 11 & 47 \\
\hline $71-80$ years & 0 & 0 & 5 & 2 & 0 & 0 & 0 & 0 & 0 & 3 & 0 & 5 & 15 \\
\hline Total & 10 & 1 & 91 & 22 & 2 & 1 & 5 & 2 & 72 & 12 & 2 & 80 & 300 \\
\hline
\end{tabular}

\section{DISCUSSION}

In this study, we found that Kennedy's class III and its modification 1 were the two most prevalent types of partial edentulism among Nepalese patients visiting Nepal Medical College, Kathmandu. Documenting the pattern of partial tooth loss among Nepalese patients can be beneficial in recognizing the prosthetic rehabilitative needs and in estimating the requirements for educational and preventive materials.
We found that a higher proportion of females were edentulous compared to male. Our finding is in alignment with the results of a previous study by Sapkota B et al. among Nepalese patients in Dhulikhel Hospital, Kathmandu University 8 . However, some earlier studies showed more males being edentulous than females ${ }^{9}$. This contradiction may be in part due to more females visiting the dental hospital and could also be attributed to the different socio-economic background 
and mal-habits like smoking and consumption of high sugar-containing diets among males than previous studies $^{10}$. We also found that partial edentulism was most common in age group of 51 to 60 years, similar to a finding of Mehmood BA et al which showed that the peak age group for tooth loss was in $4^{\text {th }}$ and $5^{\text {th }}$ decade of life ${ }^{11}$.

Similar study performed by Rahman $\mathrm{H}$ et al among 963 patients in Prosthodontics Department at the College of Dentistry, Hawler Medical University, Erbil, Iraq showed that distribution of partial edentulism as compared to maxilla and mandible were almost in equal ratio, maxilla $49.63 \%$ and mandible $50.36 \%$, supporting our study findings ${ }^{12}$.

In a study of partial edentulism based on Kennedy's classification conducted by Naveed $\mathrm{H}$ et al at Armed Forces Institute of Dentistry, Pakistan on 1000 partially edentulous patients, Kennedy's class III was most common in maxilla $(60.9 \%)$ and mandible $(46.8 \%)^{13}$. This study is in agreement with our study, as our study also reveals maximum number of cases with Kennedy's class III on both the maxillary and the mandibular arches with $31.3 \%$ and $30.3 \%$ consecutively. In another study carried out by Al-Dawairi among 200 patients in Jordan observed Kennedy's class III pattern of partial edentulism was most commonly encountered in both maxilla (47\%) and mandible $(45 \%)^{14}$. Also in a study by Sadig and Idowu in Saudi population on 422 partially edentulous patients concluded that Kennedy's classes III in both arches were more common with $20.3 \%$. Kennedy's Class III was found to be the most common pattern of partial edentulism in this study ${ }^{15}$. Also, in a study by Patel YJet conducted among the patients of Thiruvallur district, Tamil Nadu, India, Kennedy Class III pattern of edentulism was most commonly encountered in both maxilla $(56 \%)$ and mandible $(58 \%)^{16}$.

In contrast to our study, result of a study conducted by Khalil A et al. in the Department of Prosthodontics at Khyber College of Dentistry, Peshawar, Pakistan, showed that Kennedy's class IV was mostly seen in maxillary arch and Kennedy's class II modification 1 was dominant in mandibular arch ${ }^{17}$.

\section{CONCLUSION}

From the results of this study, we observed that Kennedy's class III was most common in both maxillary and mandibular arches followed by Kennedy's class III modification 1. According to gender, more number of female patients reported with partial edentulism whereas patients with age 51 to 60 were mostly affected.

5. Peltzer K, Hewlett S,Yawson AE. Prevalence of Loss of All Teeth (Edentulism) and Associated Factors in Older Adults in China, Ghana, India, Mexico, Russia and South Africa. Int. J. Environ. Res. Public Health 2014 Nov;11(11): 11308-24. Available from : https://www.researchgate.net/ publication/267573974_Prevalence_of_Loss_ of_All_Teeth_Edentulism_and_Associated_ Factors_in_Older_Adults_in_China_Ghana_India_ Mexico_Russia_and_South_Africa/doi: $10.3390 /$ ijerph111111308[PubMed]

6. McGarry TJ, Nimmo A, Skiba JF, Ahlstrom RH, Smith CR, Koumjian JH et al. Classification System for Partial Edentulism.JProsthodont2002 September;11(3):181-93.[PubMed]

7. Bharathi M, Reddy K, Babu M, Reddy G. Partial Edentulism based on Kennedy's Classification: An Epidemiological Study. J Contemporary Dental Practice, 2014 March; 15(2): 229-31. Available from :www.jaypeejournals.com/eJournals/ShowText. aspx?ID=6053\&TYP=TOP\&isPDF=YES [PubMed]

8. Sapkota B, Adhikari B, Upadhaya C. A Study of Assessment of Partial Edentulous Patients Based 
on Kennedy's Classification at Dhulikhel Hospital Kathmandu University Hospital,KathmanduUniv Med J 2013 Oct;4(44):325-27. Available from: http:// www.kumj.com.np/issue/44/325-327.pdf[Full text]

9. $\mathrm{S}$ Taipale $\mathrm{AL}$, Alalen $\mathrm{P}$, Helenius $\mathrm{H}$ et al. Edentulism among Finnish adults of working age,19781997. Community Dent Oral Epidemiol. 1999 October;27(5):353-65. Available from: http:// www.academia.edu/30462073/Edentulism_ among_Finnish_adults_of_working _ age_1978_1997[PubMed]

10. Hoover JN, Mc Dermott RE. Edentulousness in patient attending a University Dental clinic. J Can Dent. Assoc. 1989 March;55(2):139-40.[PubMed]

11. Mehmood BA, Rahoojo A, Punjabi KS, LalR.Incidence of various Kennedy's Classes in Partially Edentulous patients visiting Dental OPD Hyderabad/Jamshoro. Pakistan Oral and Dental J. 2015 June; 35(2):32931. Available from: https://www.researchgate. net/publication/311899947_INCIDENCE_OF_ VARIOUS_KENNEDY\%27S_CLASSES_IN_PARTIALLY_ EDENTULOUS_PATIENTS_VISITING_DENTAL_OPD_ HYDERABADJAMSHORO[DOI]

12. Rahman $\mathrm{H}$, Tahir DC, Saleh MM. Incidence of partial edentulism and its relation with age and gender. Zanco J. Med. Sci., 2013;17(2):463-70. Available from: http://zjms-hmu.org/files/articles/270813040653. pdf[Full text]
13. Naveed H, Aziz M, Hassan A. Patterns of partial edentulism among Armed Forces personnel reporting at armed forces institute of dentistry Pakistan. Pak Oral and Dent J. 2011 June;31(1):217-18. Available from: http://podj.com.pk/archive/Jul_2011/50-Podj. pdf[PubMed]

14. Al-Dawairi ZN. Partial edentulism and removable denture construction: A frequency study in Jordanians. Eur J Pros Restor Dent. 2006 March;14(1):13-17. [PubMed]

15. Sadig WM, Idowu AT. Removable partial denture design. A study of selected population in Saudi Arabia. J Cont Dent Prac. 2002 November;3(4):1-11. Available from: https://pdfs.semanticscholar.org/ca23/7669721b 4dcbc6f64a37922936d76aeb18c5.pdf[Full text]

16. Patel YJ, Vohra YM, Hussain MJ. Assessment of Partially Edentulous Patients Based on Kennedy's Classification and its Relation with Gender Predilection.Intl J of Sci Study 2014 September;2(6):32-36. Available from: http://asnanportal.com/images/edentolous_pt.pdf[Full text]

17. Khalil A, Hussain U, Iqbal R, Ali W. Patterns of partial edentulism among patients reporting to Department of Prosthodontics, Khyber College of Dentistry, Peshawar. J Khyber CollegeDent. 2013 June;3(2):42-45. Available from: http://www.jkcd.org.pk/Issues/June-2013/JKCD9.pdf[Full text] 